\title{
Heteroduplex Study of the Sequence Relations Between RD-114 and Baboon Viral RNAs ${ }^{1}$
}

\author{
SYLVIA HU, ${ }^{2}$ NORMAN DAVIDSON, ${ }^{*}$ MARGERY O. NICOLSON, AND ROBERT M. MCALLISTER \\ Department of Chemistry, California Institute of Technology, Pasadena, California 91125,*and Department \\ of Pediatrics, University of Southern California School of Medicine, Childrens' Hospital of Los Angeles, Los \\ Angeles, California 90054
}

Received for publication 7 March 1977

\begin{abstract}
The regions of sequence homology and nonhomology between the RNA genomes of RD-114 and baboon endogenous type $C$ viruses have been mapped by an electron microscope heteroduplex study. Short complementary DNA (cDNA) copies (approximately 150 to 200 nucleotides in length) of RD-114 RNA were prepared by an endogenous synthesis; labels of polydeoxythymidylic acid [poly $(\mathrm{dT})]$ were attached to the $3^{\prime}$ ends of the cDNA molecules by a reaction catalyzed by deoxynucleotidyl terminal transferase. The cDNA-poly(dT) was hybridized to RD-114 RNA and to baboon viral RNA dimer (50 to 70S) units, and the positions of the poly (dT) labels were observed by electron microscopy. With RD-114, labels were distributed uniformly along the genome. With baboon virus RNA (monomer length, 9.5 kilobases [kb]), the regions of high homology with RD-114 cDNA were observed to lie in the intervals from 1.5 to $2.5 \mathrm{~kb}$ and from 3.7 to $5.5 \mathrm{~kb}$ from the $5^{\prime}$ end. The relations of these heteroduplex maps to the known antigenic similarities and differences among the several viral proteins and to the genetic maps of the viruses are discussed.
\end{abstract}

Several closely related endogenous type $\mathrm{C}$ viruses have been isolated from Papio cynocephalus baboon sources $(5,6,19,33)$, including the BAB-8-K (BKD) virus that we study here and that was isolated by cocultivation of iododeoxyuridine-treated baboon kidney cells with dog thymus cells (33). RD-114 is an endogenous xenotropic virus of normal feline cells $(1,14,15$, $22,23,26,27)$. The RD-114 and baboon viruses are related in many respects and are unrelated to other known type $C$ viruses $(16,29)$. The two viruses have a similar host range and show reciprocal interference and a degree of crossneutralization in tissue culture (16). The major structural protein p30 and reverse transcriptase proteins also have related antigenic determinants $(16,29)$. Thus, the products of the env, $\mathrm{gag}$, and pol genes of the two viruses are immunologically similar. Molecular hybridization studies, however, show a clear distinction between the RNA genomes of the two viruses that are only 10 to $20 \%$ related $(5,32)$. RD-114-related nucleic acid sequences are found in four closely related species of Felidae, but not in other Felidae genomes (9). They are also found

${ }^{1}$ Contribution no. 5504 from the Department of Chemistry, California Institute of Technology, Pasadena, CA 91125.

2 Present address: Department of Microbiology, University of Southern California School of Medicine, Los Angeles, CA 90033 . in the genomes of all Old World monkey and ape tissues (7). These observations have led to the suggestion that RD-114 evolved from an endogenous primate type $\mathrm{C}$ virus that infected and became endogenous in a recent ancestor of the domestic cat (6).

The high-molecular-weight (50 to 70S) RNA genomes of RD-114 and BKD virus have been shown to be dimers, consisting of two monomers of about 10 kilobases (kb) (" $35 \mathrm{~S}$ ") joined to each other close to their $5^{\prime}$ ends, with a large secondary structure loop close to the middle of each monomer and with the $3^{\prime}$ ends containing polyadenylic acid [poly(A)] stretches $(3,21)$. Studies from these laboratories suggest that the structure is characteristic of all mammalian type $C$ viruses $(12,17)$. The lengths of the several structural features are different for different viral RNAs; however, BKD and RD-114 are very similar. Because of all these relationships between the two viruses, it was of interest to map the regions of sequence homology and nonhomology of the RNA genomes by the electron microscope heteroduplex method. As applied to RNA tumor viruses $(17,18)$, heteroduplex analysis involves the hybridization of a complementary DNA (cDNA) transcript prepared from one viral RNA to the other viral RNA and the observation in an electron microscope of the regions along the RNA strand that are hybrid and that are single stranded. In the 
present instance the cDNA transcripts of RD114 RNA that were prepared were quite short. This makes it difficult to discriminate between an RNA:DNA hybrid region and a singlestranded stretch of RNA. We therefore adopted the expedient of attaching a label to the cDNA by synthesizing a polydeoxythymidylic acid [poly(dT)] tail of a length of approximately 200 nucleotides onto the $3^{\prime}$ end of the cDNA, using TTP as a substrate and the enzyme deoxynucleotidyl terminal transferase as a catalyst. As will be seen, the label greatly assists in the mapping of RNA:DNA hybrid regions in heteroduplexes.

\section{MATERIALS AND METHODS}

Virus and RNA preparations. RD-114 virus was obtained by harvesting supernatant culture fluid from the RD-114 cell line (13). BKD virus (33) was propagated on the human HT-1080 cell line (25). Viruses were harvested at 3 -h intervals and purified by isopycnic banding in a 24 to $48 \%$ sucrose gradient in NTE buffer $(0.1 \mathrm{M} \mathrm{NaCl}-0.01 \mathrm{M}$ Tris-0.001 M EDTA [pH 7.5]). Virus fractions were pooled and, if the endogenous reverse transcriptase reaction was to be performed, the fractions were stored in $15 \%$ sucrose-NTE at $-70^{\circ} \mathrm{C}$. Otherwise, the 50 to $70 \mathrm{~S}$ RNA was extracted from the virus as described previously (20).

Synthesis of RD-114 cDNA. Purified RD-114 virus was incubated for $24 \mathrm{~h}$ at $37^{\circ} \mathrm{C}$ in $1 \mathrm{ml}$ of a mixture containing 0.4 or $1 \mathrm{mM}$ dATP, dCTP, and dGTP, 2 $\mathrm{mM}$ manganese chloride, $10 \mathrm{mM}$ dithiothreitol, 40 $\mathrm{mM}$ Tris-hydrochloride ( $\mathrm{pH} 8.2), 50 \mathrm{mM} \mathrm{KCl}, 0.1 \%$ Nonidet $\mathrm{P}-40,50 \mu \mathrm{g}$ of actinomycin D per ml, $2.4 \mu \mathrm{M}$ $\left.{ }^{3} \mathrm{H}\right]$ TTP (42 Ci/mmol; Schwarz/Mann). Sometimes $0.1 \mathrm{mM}$ unlabeled TTP was added. The calculated specific activity of the resulting cDNA was $3.8 \times 10^{7}$ $\mathrm{cpm} / \mu \mathrm{g}$. The reaction was terminated by the addition of EDTA ( $\mathrm{pH} 7.50$ ) to $0.01 \mathrm{M}$ and of sodium dodecyl sulfate (SDS) to $0.5 \%$. Self-digested proteinase $\mathrm{K}$ was added to $500 \mu \mathrm{g} / \mathrm{ml}$, and the mixture was incubated at $37^{\circ} \mathrm{C}$ for $45 \mathrm{~min}$. The mixture was then extracted with phenol, 50 to $100 \mu \mathrm{g}$ of yeast-tRNA per $\mathrm{ml}$ was added as carrier, and the nucleic acid was precipitated with ethanol. To destroy the RNA, the product was dissolved in $3 \mathrm{mM}$ EDTA ( $\mathrm{pH} 7.50$ ) and incubated with $100 \mu \mathrm{g}$ of RNase $\mathrm{A}$ (Worthington Biochemicals Corp.) per ml at $37^{\circ} \mathrm{C}$ for $1 \mathrm{~h}$. NaOH was then added to $0.6 \mathrm{~N}$, and incubation was continued for $1 \mathrm{~h}$ more at $37^{\circ} \mathrm{C}$. The hydrolysate was neutralized with $\mathrm{HCl}$, dialyzed into $0.01 \mathrm{M}$ Tris-hydrochloride-0.001 M EDTA ( $\mathrm{pH} 7.50$ ), phenol extracted, ethanol precipitated, and stored at $-70^{\circ} \mathrm{C}$.

Terminal transferase reaction. The reaction mixture in $30 \mu \mathrm{l}$ contained $0.05 \mathrm{M}$ cacodylic acid, $0.1 \mathrm{M}$ potassium phosphate ( $\mathrm{pH} 7.0$ ), $1 \mathrm{mM}$ cobalt chloride, $1.5 \mathrm{mM}$ dithiothreitol, $3 \mathrm{mM}$ TTP, $1.3 \mu \mathrm{g}$ of cDNA per $\mathrm{ml}, 30 \mathrm{U}$ of terminal transferase (P. L. Biochemicals) per ml. Incubation was performed at $37^{\circ} \mathrm{C}$ for $23 \mathrm{~h}$. The reaction was terminated by adding $0.02 \mathrm{M}$ EDTA. The product was stored at $-70^{\circ} \mathrm{C}$ and used without deproteinization. The number average length of the poly (dT) extensions synthesized under these conditions was 150 to 200 nucleotides.

Poly(A)-Sepharose column. Poly(A)-Sepharose was prepared by the cyanogen bromide coupling method of Berridge and Aronson (10), using $0.2 \mathrm{~g}$ of $\mathrm{CNBr}$ per ml of packed Sepharose. The sample to be absorbed to the poly(A)-Sepharose was mixed with 1 $\mathrm{ml}$ of $0.1 \mathrm{M} \mathrm{NaCl}-0.01 \mathrm{M}$ Tris-0.001 M EDTA- $0.2 \%$ SDS ( $\mathrm{pH}$ 7.5) and loaded onto a column of $1-\mathrm{ml}$ bed volume at a rate of about $0.5 \mathrm{ml} / \mathrm{min}$ at $22^{\circ} \mathrm{C}$. The column was eluted first with $0.1 \mathrm{M} \mathrm{NaCl}-0.01 \mathrm{M}$ Tris- $0.001 \mathrm{M}$ EDTA- $0.2 \%$ SDS (pH 7.5) at $25^{\circ} \mathrm{C}$ and then with the same buffer without $0.1 \mathrm{M} \mathrm{NaCl}$ and with an increasing temperature gradient up to $60^{\circ} \mathrm{C}$. One-milliliter fractions were collected for each $2^{\circ}$ span in temperature. Aquasol was added to a portion of each fraction for counting.

Hybridization. The 50- $\mu \mathrm{l}$ reaction mixture contained $50 \%$ formamide, $0.65 \mathrm{M} \mathrm{NaCl}, 0.1 \mathrm{M}$ Trishydrochloride, and 0.01 M EDTA ( $\mathrm{pH} 8.5$ ). In some experiments, diethyl pyrocarbonate was added to $1 \%$ to inhibit RNase. (Nucleic acids were then not added until at least 15 min after adding the diethyl pyrocarbonate.) There was no noticeable difference in RNA lengths between experiments with and without diethyl pyrocarbonate. cDNA-poly(dT) at 0.25 to $0.45 \mu \mathrm{g} / \mathrm{ml}$ and viral RNA at 1.0 to $1.6 \mu \mathrm{g} / \mathrm{ml}$ were incubated in this solvent for $3 \mathrm{~h}$ at $52^{\circ} \mathrm{C}$.

Glyoxal treatment and spreading. The hybridization product was dialyzed for $3 \mathrm{~h}$ at $37^{\circ} \mathrm{C}$ against $1 \mathrm{M}$ glyoxal-0.01 $\mathrm{M}$ sodium phosphate $(\mathrm{pH} 7.0)$, as described previously (20). Portions were then mounted by the formamide Kleinschmidt technique ( $55 \%$ onto $18 \%$ formamide) as described by Sharp et al. (28).

Formamide-polyacrylamide gel electrophoresis. The size distribution of the cDNA product was determined by electrophoresis in $5 \%$ polyacrylamide gels containing $98 \%$ formamide, as described by Staynov et al. (30). Gels $(0.8$ by $10 \mathrm{~cm}$ ) were prerun for $2 \mathrm{~h}$ at $100 \mathrm{~V}$ (about $10 \mathrm{~V} / \mathrm{cm}$ ). Electrophoresis was at $100 \mathrm{~V}$ for $12 \mathrm{~h}$. Three duplex DNA fragments of defined length R3 (670 base pairs [bp]), R5 (400 bp), and R9 (155 bp) (A. S. Lee, Ph.D. dissertation, California Institute of Technology, Pasadena, 1975), derived from $\phi \mathrm{X} 174$ replicative-form (RF) DNA by digestion with HinfI restriction endonuclease, were used as internal length markers. The gels were stained in 1 $\mu \mathrm{g}$ of ethidium bromide per $\mathrm{ml}$ to locate the marker bands, sliced into 2-mm slices, and counted in Aquasol.

\section{RESULTS}

Characterization of RD-114 cDNA. The yield of cDNA was variable in different experiments, from less than 1 to $15 \%$ of the input viral RNA. The reactions that gave the highest yields were with a virus preparation that had been frozen for 2 years. The average size of the cDNA was rather small, usually between 150 and 200 nucleotides.

Efficiency of terminal transferase reaction. Purified ${ }^{3} \mathrm{H}$-labeled RD-114 cDNA was incubated with unlabeled TTP and terminal trans- 
ferase. The product was analyzed on a poly(A)Sepharose column (Fig. 1). Over 95\% of the cDNA bound to the column in the high-salt buffer (described above) at $24^{\circ} \mathrm{C}$ and was eluted in the low-salt buffer over a narrow temperature range around $50^{\circ} \mathrm{C}$-the expected melting temperature for polydeoxyadenylic acid. poly(dT) duplexes. Therefore, most of the cDNA had been extended with poly(dT) after the reaction.

Size determination of RD-114 cDNA before and after poly $(\mathrm{dT})$ extension. The length distributions of the RD-114 cDNA before and after extension with poly $(\mathrm{dT})$ were determined by electrophoresis on a $5 \%$ polyacrylamide gel containing 98\% formamide (Fig. 2). Several $\phi$ X174 RF DNA fragments produced by digestion with HinfI restriction endonuclease were denatured

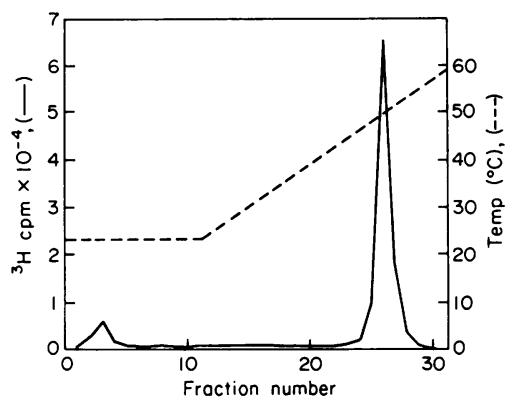

Fig. 1. Elution profile of RD-114 cDNA-poly $(d T)$ from a poly (A)-Sepharose column. The solid line depicts the ${ }^{3} \mathrm{H}$ counts in the $\mathrm{CDNA}$, and the dashed line indicates the temperature of elution. The column was loaded and first washed with a high-salt buffer for fractions 1 to 8. This was followed by low-salt elution at increasing temperature. For full details, see the text.

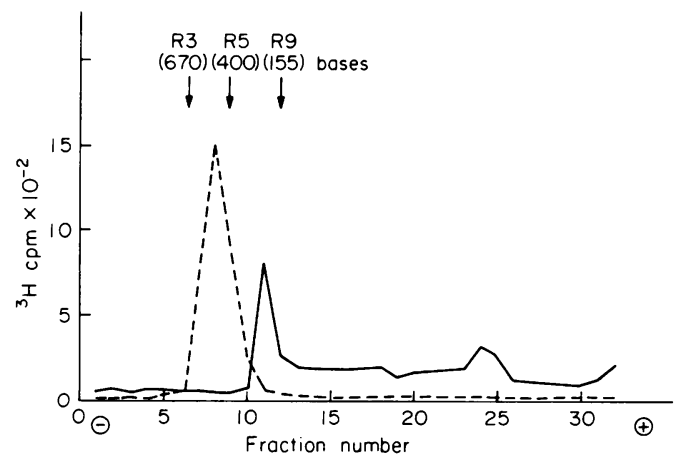

FIG. 2. Formamide-polyacrylamide gel electrophoresis of ${ }^{3} \mathrm{H}$-labeled $\mathrm{RD}-114 \mathrm{cDNA}$ before (-) and after (--) the terminal transferase reaction. Migration is from left to right. Unlabeled, denatured $\phi X 174$ fragments of defined sizes were used as internal markers. and used as markers. Most of the cDNA migrates in a fairly sharp band, with lengths extending from 155 to 260 nucleotides and a maximum at 205. After extension, the length distribution extended from 300 to 670 nucleotides, with a maximum at 470 . Thus the average amount of dT added was 265 nucleotides.

Formation of RD-114 RNA/RD-114 cDNA homoduplexes. As a control for the heteroduplex studies, RD-114 cDNA extended with poly(dT) was hybridized to an RD-114 RNA preparation containing many dimer molecules.

The hybridization mixture contained RNA in a fivefold excess because the amount of cDNA available was small. Two typical hybrid molecules are shown in Fig. 3. These micrographs show RNA dimers with many poly(dT) labels emerging from the RNA.

The positions of the poly(dT) labels on all molecules with recognizable dimer linkage structures (DLS) were scored. Not all of these RNA molecules were of full length. The number of strands of a given length starting at the DLS was measured. The number of poly $(\mathrm{dT})$ labels at a given distance from the DLS was measured. The probability of finding a poly $(\mathrm{dT})$ tail at a given distance from the DLS in fulllength molecules was then calculated. The resulting histogram (Fig. 4a) shows that the cDNA hybrid regions were more or less uniformly distributed over the entire RNA genome.

We estimate that the average number of poly(dT) labels visible on each full-length $(9.8$ kb) RNA monomer unit was about 15 . We consider 200 nucleotides to be the average length of a cDNA transcript and calculate an average fractional coverage of the RNA as $(15 \times 200)$ / 9,800 or 0.31 . This ratio is approximately the same as the input ratio of 1:5 of cDNA to RNA, suggesting that the transcript is a more or less uniform copy of the RNA. In agreement with this conclusion, Bailey (personal communication) observed that when the cDNA was hybridized to ${ }^{125}$ I-labeled RD-114 50 to 70S RNA at a mass ratio of cDNA to RNA of $2: 1,85 \%$ of the RNA was protected from RNase A digestion.

Several other points of interest may be noted. A poly(A) end of the 50 to 70S RNA was frequently hybridized to a poly (dT) label close to the end, giving a small circle. Examples are shown in Fig. 3a and b. In some cases, poly (dT) labels appeared to emerge from the dimer linkage structure, suggesting that the thick structure seen in the electron microscope is not all duplex.

RD-114 cDNA/BKD RNA heteroduplexes. When RD-114 cDNA-poly(dT) was hybridized to 


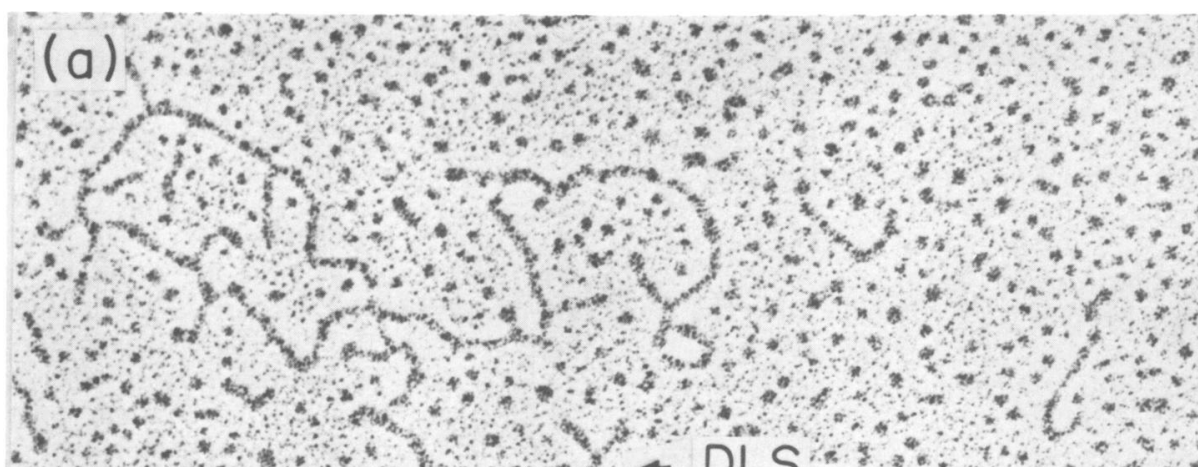

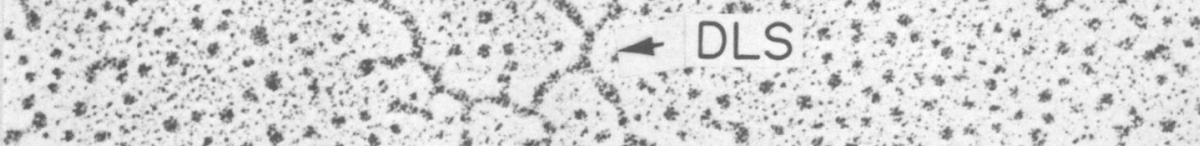

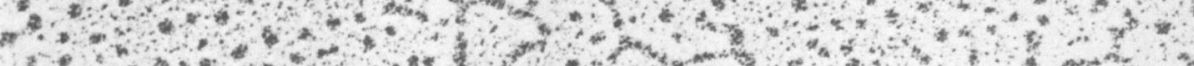

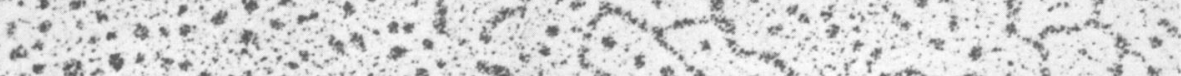

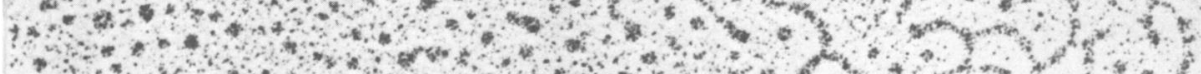

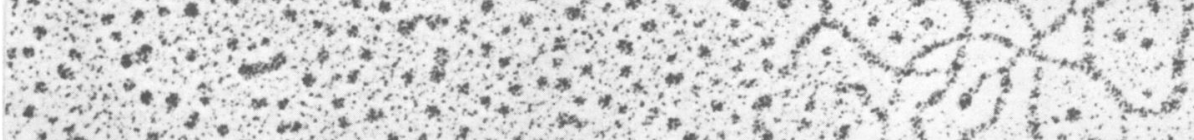

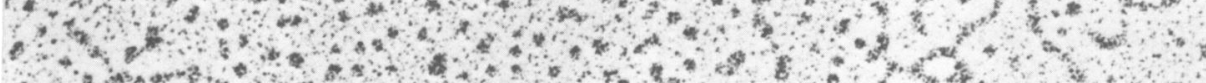

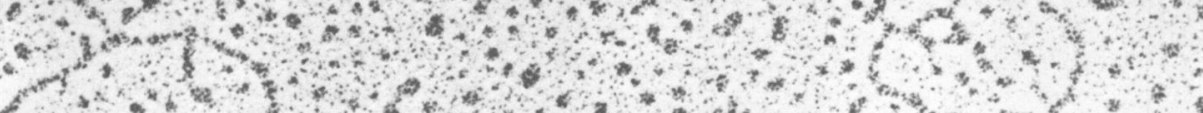

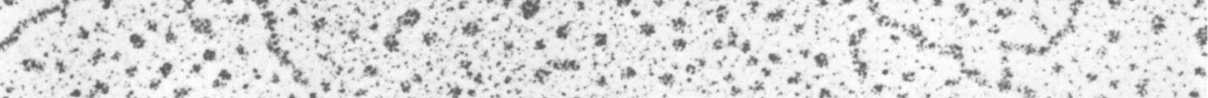

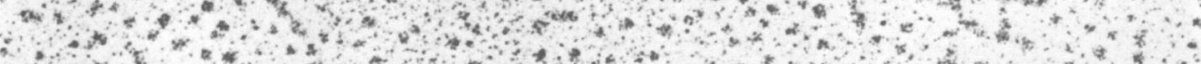

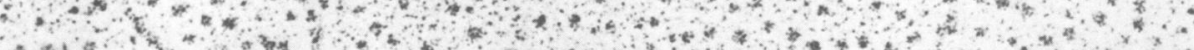

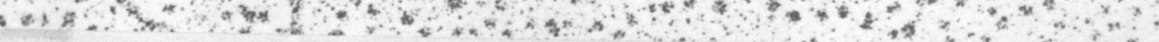

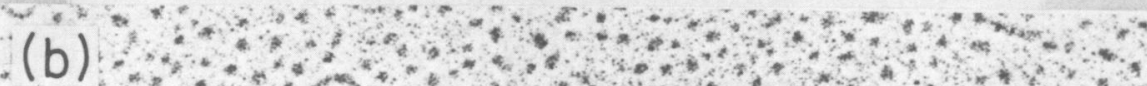

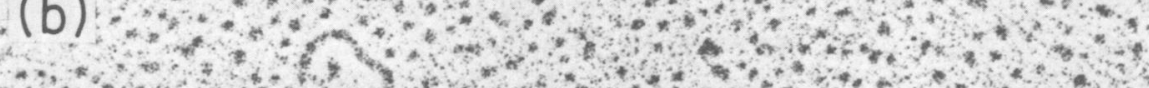

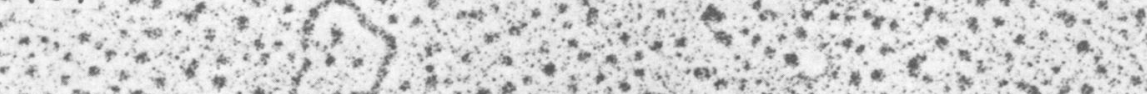

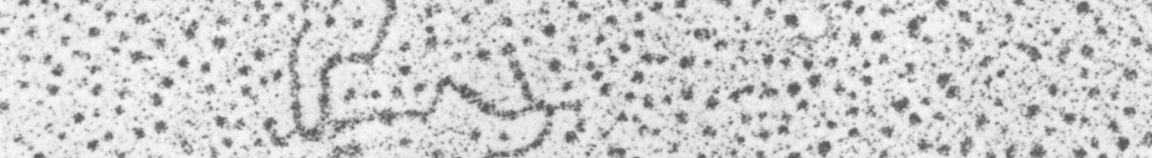

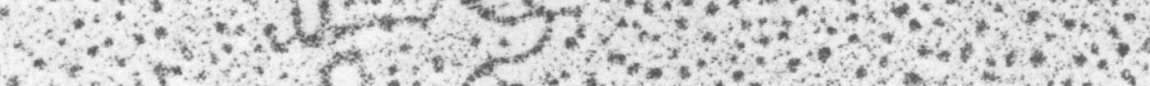

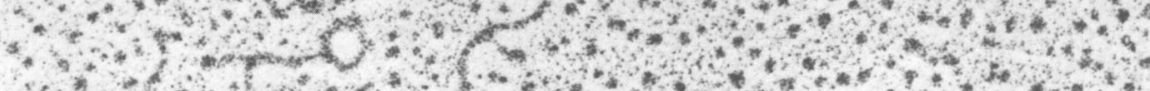

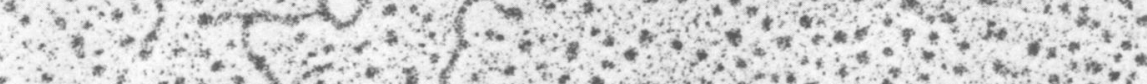

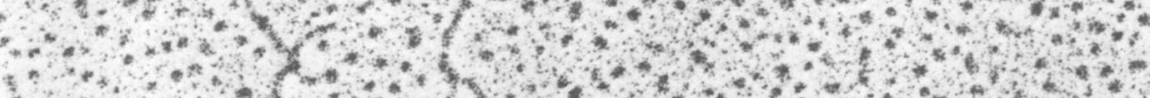

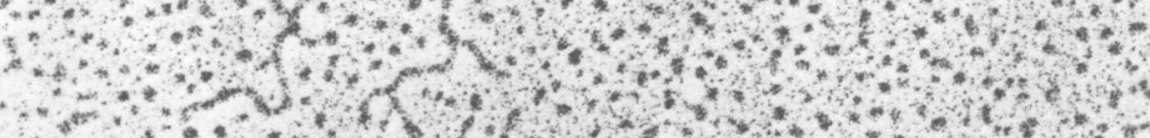

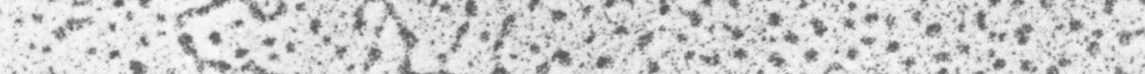

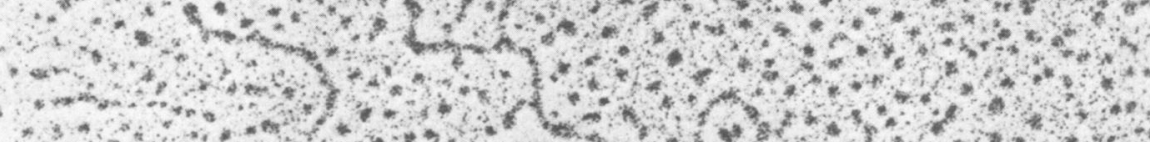

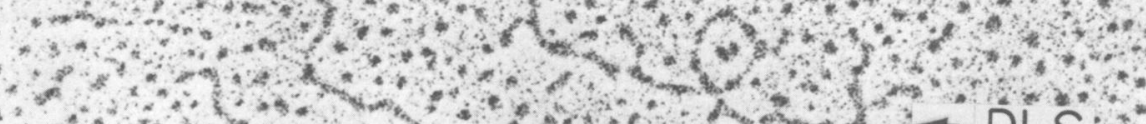

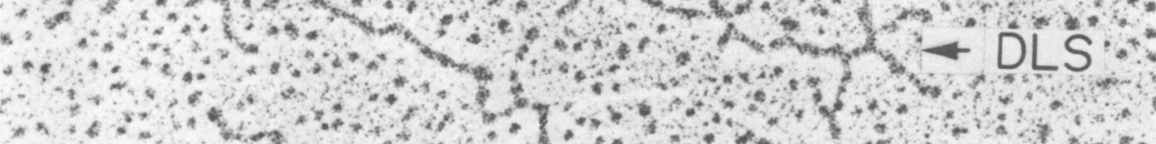

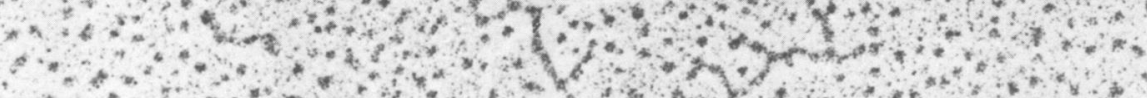

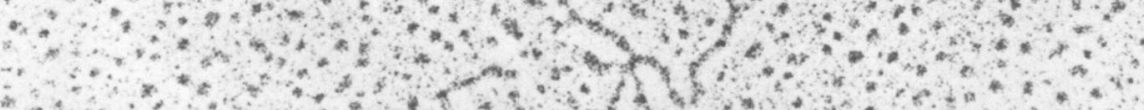

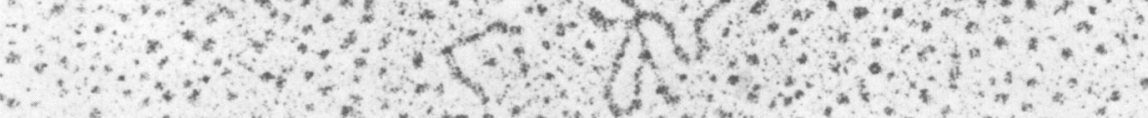

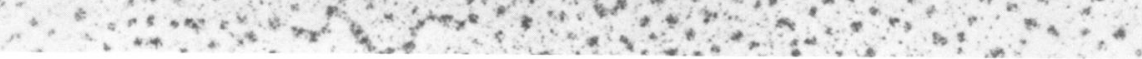


RD -114 (or BKD) RNA
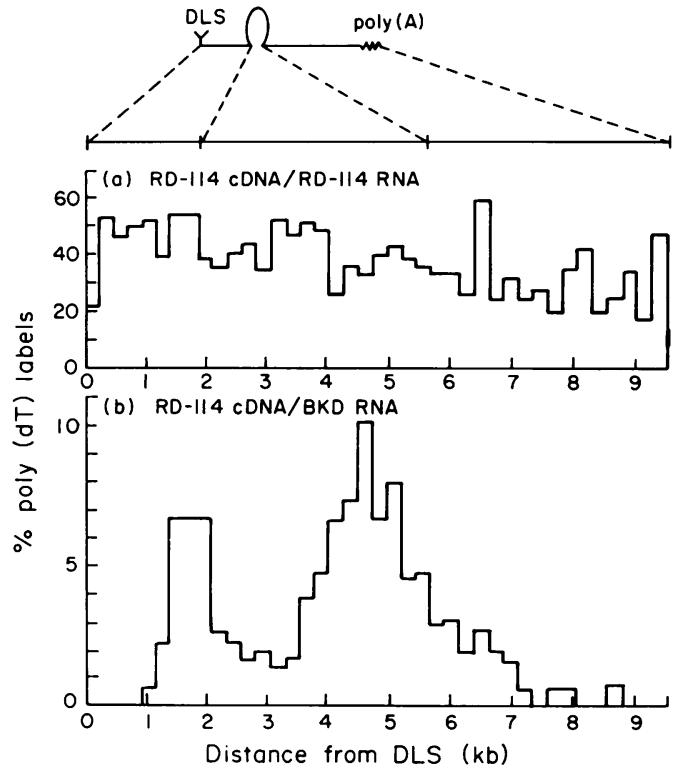

Fig. 4. Maps of the regions on (a) RD-114 RNA and (b) BKD RNA that hybridize with RD-114 $c D N A-p o l y(d T)$. On the top of the figure is a schematic presentation of the subunit structure common to both $R D-114$ and $B K D$. In (a), the histogram was made by scoring the frequency of hybrid poly $(d T)$ observed at each region, divided by the frequency of occurrence of that particular region in all the molecules scored. This method reduces the tendency to overestimate the contribution of regions closer to the marker. A representative population was made by scoring all the hybrid molecules with a clear DLS or $\operatorname{poly}(A)$ end. A similar procedure was followed in constructing histogram (b), but only 20 to $30 \%$ of the total BKD RNA molecules were found to have hybrid structures. The data for RD-114/RD-114 homoduplexes were obtained from 86 monomer units in dimers with a recognizable DLS. Of these, 16 monomers were full length. The BKD RD-114 data were obtained from 130 monomer units in dimers with a recognizable DLS, of which 32 were full length. In each case, there was an approximately linear increase in the size of the sample scored as the length decreases from 9.5 to $0 \mathrm{~kb}$.

a fourfold excess of 50 to 70S RNA of the baboon endogenous (BKD) virus, hybrid structures were seen. The number of labels per RNA molecule was clearly less than for RD-114 RNA, and many of the RNA molecules did not have any poly (dT) labels. In three independent experi- ments, data were collected from a total of 120 BKD RNA/RD-114 cDNA-poly(dT) hybrid molecules, which clearly showed one or more poly(dT) labels. Two examples are shown in Fig. 5.

The positions of the hybrid regions were mapped relative to the BKD DLS (which did not hybridize to the RD-114 cDNA). As was done for RD-114, corrections were made to obtain the frequency of hybrids occurring along the whole genome. The resulting histogram is shown in Fig. $4 \mathrm{~b}$.

\section{DISCUSSION}

Two other heteroduplex studies of the sequence relations of tumor virus RNAs have been reported from this laboratory, dealing with the Mo-MSV/Mo-MLV (17) system and with the RSV/RSVtd system (18). In those cases it was possible to prepare long cDNA transcripts of one genome and obtain long heteroduplex molecules. It was thus possible to obtain fairly precise mapping data for the regions of homology and nonhomology. We have not yet succeeded in synthesizing long cDNA from RD114 or BKD viruses. Nevertheless, as shown in Fig. 4, significant information about the regions of homology and nonhomology between these two viral genomes has been obtained.

Before discussing the data, we wish to note several sources of uncertainty that limit the accuracy with which interpretations can be made. First, due to experimental difficulties, the heteroduplex map of Fig. 4 is not very accurate. Second, if a region of a heteroduplex is observed to be duplex, the two complementary sequences are not necessarily perfectly complementary. The conditions of spreading for electron microscopy allow for some partial (perhaps 10 to $20 \%$ ) random sequence mismatch (11).

Our principal result is shown in the histogram of Fig. 4b. A high frequency of hybrids occurs at two regions near the $5^{\prime}$ end of the BKD RNA genome, from 1.5 to $2.5 \mathrm{~kb}$ and from about 3.7 to about $5.5 \mathrm{~kb}$. We consider these to be regions of high sequence homology between the two RNAs. There is no evidence for homology immediately adjacent to the $5^{\prime}$ or the $3^{\prime}$ end. There appears to be a lower frequency of hybrid formation from 2.5 to $3.7 \mathrm{~kb}$ and from 5.5 to $7.0 \mathrm{~kb}$; these may be regions of partial sequence homology.

FIG. 3. Two typical molecules of RD-114 cDNA-poly(dT)/RD-114 50 to $70 S$ RNA homoduplexes. There are many poly(dT) tails on each molecule. Notice the small circles formed between the poly $(A)$ end and the poly(dT) from the cDNA, which indicates that both are complete molecules. The DLS in these two molecules are indicated by arrows. The molecule on the bottom has its DLS hybridized to three segments of cDNA$\operatorname{poly}(d T)$. 


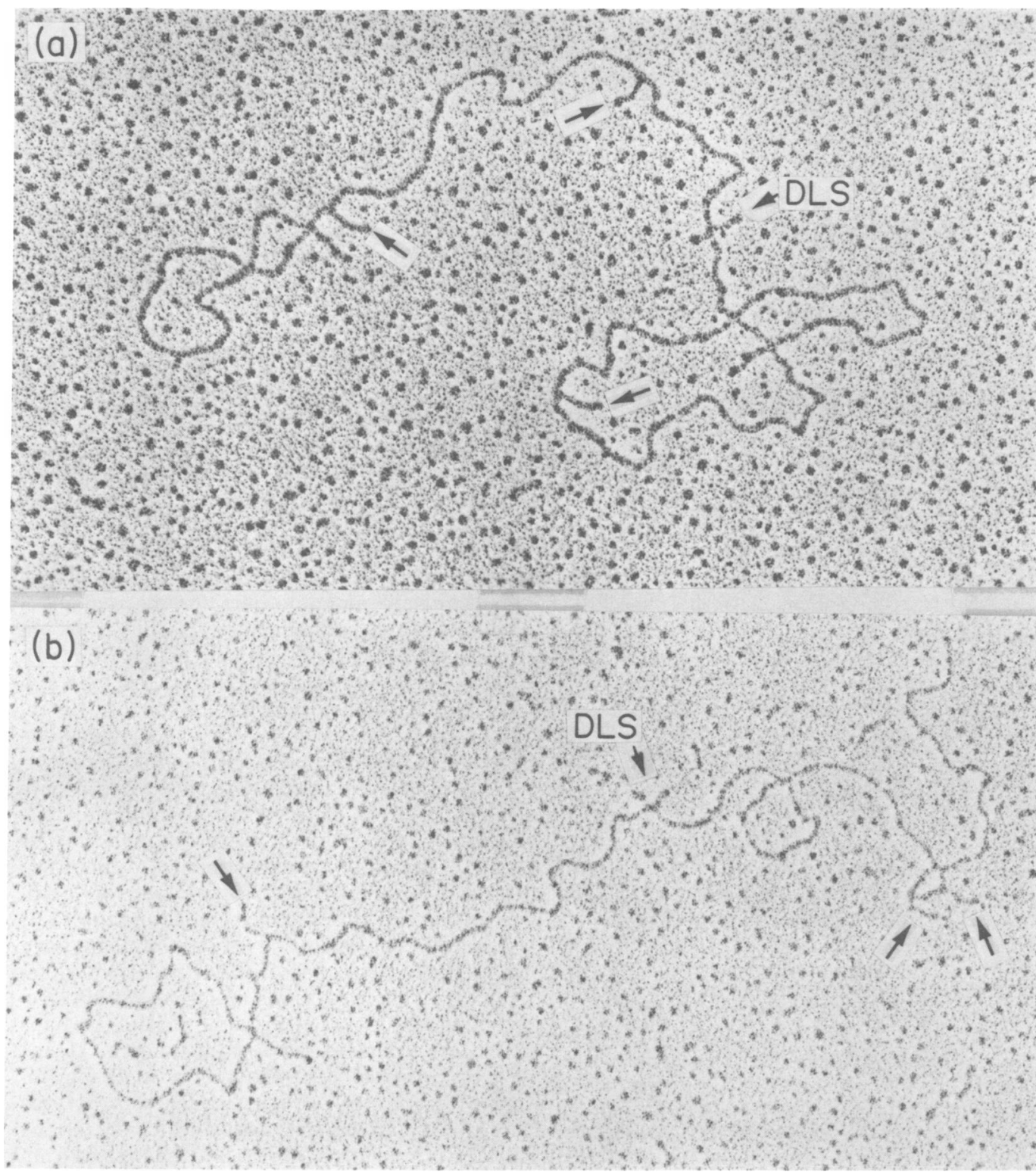

Fig. 5. Examples of the heteroduplexes between RD-114 cDNA-poly(dT) and BKD 50 to $70 S$ RNA. The $D L S s$ of these two molecules are marked by arrows. Each RNA molecule is full length and has three regions hybridized to the cDNA. These regions can be identified by the poly $(d T)$ extensions, which are indicated by arrows.

The regions of high sequence homology (1.5 to $2.5 \mathrm{~kb}$ and 3.7 to $5.5 \mathrm{~kb}$ ) correspond to $30 \%$ of the baboon or RD-114 viral genome; the regions of lower sequence homology (2.5 to 3.7 and 5.5 to $7.0 \mathrm{~kb}$ ) correspond to an additional $28 \%$ of the viral genome. Molecular hybridization experiments involving an S1 nuclease assay of the amount of hybridization of RD-114 and baboon viral cDNA probes to cat and baboon cellular DNAs (containing integrated RD-114 and ba- boon viral genomes, respectively) indicate 20 to $30 \%$ sequence homology between the two viral genomes (4). A similar experiment with a baboon viral cDNA probe and cellular RNA from RD-114 producer cells indicates $10 \%$ sequence homology (5). Thus, electron microscope and S1 assay hybridization experiments are in rough agreement in indicating $20 \pm 10 \%$ high-sequence homology between the two genomes.

Immunological experiments indicate cross- 
reactivity between antiserum to $\mathrm{RD}-114$ reverse transcriptase and the baboon enzyme and between the respective p30 group-specific antigens $(16,29)$. Antiserum to RD-114 virus will partially inactivate the baboon virus and vice versa (16). We take this result to indicate that the envelope glycoproteins of the two viruses share antigenic determinants.

Thus, all three of the major known gene products of the two viruses - the gag proteins, the reverse transcriptase, and the envelope glycoprotein-are somewhat related. But it is not possible to quantitatively correlate antigenic relatedness to amino acid sequence relatedness, or amino acid relatedness to nucleic acid sequence relatedness.

The probable gene order for avian viruses is 5 ' gag-pol-env-src-C (constant region)-polyA (P. K. Vogt, In H. Fraenkel-Conrat and R. R. Wagner, ed., Comprehensive Virology, in press). In replication-effective murine viruses, the relative order of the three genes gag, pol, and env is almost certainly $5^{\prime}$ gag-pol-env, just as for avian viruses. Translation normally initiates close to the $5^{\prime}$ end of a polycistronic eucaryotic message, and the most abundant translation products in virus-infected cells are the gag gene products or their polypeptide precursors (2; G. A. Jamjoon, R. B. Naso, and R. B. Arlinghaus, Virology, in press). Furthermore, a heteroduplex study of Mo-MSV and Mo-MLV suggests that the gag genes are in a region close to the $5^{\prime}$ end (17). The presence of reverse transcriptase antigenic determinants as well as gag determinants on a 200,000-dalton polypeptide precursor, but of only gag determinants on an 80,000 dalton precursor, suggests that the pol gene is immediately in the $3^{\prime}$ side of the gag genes (Jamjoon et al., in press).

The precursor polypeptide translation product of the murine gag genes has a molecular weight of 65,000 to 68,000 , corresponding to a nucleotide length of about 1,800 nucleotides. If we assume that RD-114 and the baboon virus have a genetic map that is similar to that of murine viruses, we conclude that the region of homology from 1.5 to $2.5 \mathrm{~kb}$ is related to gag gene products. The lack of homology from 0 to $1.0 \mathrm{~kb}$ from the $5^{\prime}$ end suggests, however, that some of the gag gene products of the two viruses are quite different in sequence. Indeed, it is known that there is much less immunological cross-reaction between the respective p15 proteins of the two viruses than between their p30 proteins (31).

If the murine pol gene product is included in a 200,000-dalton precursor polypeptide, and if translation starts at the $5^{\prime}$ end (Jamjoon et al., in press), the pol gene must lie within $5.5 \mathrm{~kb}$ of the $5^{\prime}$ end. The murine reverse transcriptase has a molecular weight of 84,000 , corresponding to $2.3 \mathrm{~kb}$ of nucleotide sequence. Thus, about $1.0 \mathrm{~kb}$ of the 5.5 -kb region corresponding to the 200,000-dalton precursor polypeptide codes for amino acid sequences that are not part of the mature gag or pol gene products. At the present time, therefore, we cannot assign either the region of partial sequence homology from 2.5 to $3.7 \mathrm{~kb}$ or the region of higher sequence homology from 3.7 to 5.5 of the two genomes as the coding region for the reverse transcriptase.

The data available at present are not sufficient to permit a reliable assignment of the env gene relative to the heteroduplex map.

\section{ACKNOWLEDGMENTS}

This research was supported by Public Health Service contracts NO1 CP 43306 and PH 43-68-1030 from the Virus Cancer Program of the National Cancer Institute.

We thank Welcome Bender for guidance and advice on terminal transferase reactions. We also thank Marie Krempin and Mary Peer for technical assistance.

\section{LITERATURE CITED}

1. Baluda, M. A., and P. Roy-Burman. 1973. Partial characterization of RD-114 virus by DNA-RNA hybridization studies. Nature (London) New Biol. 244:59-62.

2. Barbarid, M., J. R. Stephenson, and S. A. Aaronson. 1976. Gag gene of mammalian type-C RNA tumor viruses. Nature (London) 262:554-559.

3. Bender, W., and N. Davidson. 1976. Mapping of poly(A) sequences in the electron microscope reveals unusual structure of type $\mathrm{C}$ oncornavirus RNA molecules. Cell 7:595-607.

4. Benveniste, R. E., R. Heinemann, G. L. Wilson, R. Callahan, and G. J. Todaro. 1974. Detection of baboon type $\mathrm{C}$ viral sequences in various primate tissues by molecular hybridization. J. Virol. 14:56-67.

5. Benveniste, R. E., M. M. Lieber, D. M. Livingston, C. J. Sherr, G. J. Todaro, and S. S. Kalter. 1974. Infections C-type virus isolated from a baboon placenta. Nature (London) 248:17-20.

6. Benveniste, R. E., and G. J. Todaro. 1974. Evolution of C-type viral genes: inheritance of exogenously acquired viral genes. Nature (London) 252:456-459.

7. Benveniste, R. E., and G. J. Todaro. 1974. Evolution of type C-viral genes. I. Nucleic acid from baboon type$\mathrm{C}$ virus as a measure of divergence among primate species. Proc. Natl. Acad. Sci. U.S.A. 71:4513-4518.

8. Benveniste, R. E., and G. J. Todaro. 1974. Multiple divergent copies of endogenous C-type virogenes in mammalian cells. Nature (London) 252:170-173.

9. Benveniste, R. E., and G. J. Todaro. 1975. Segregation of RD-114 and FeLV-related sequences in crosses between domestic and leopard cat. Nature (London) 257:506-508.

10. Berridge, M. V., and A. I. Aronson. 1973. An assay for the endonucleolytic cleavage of RNA to large oligonucleotides. Anal. Biochem. 53:603-612.

11. Davis, R. W., M. Simon, and N. Davidson. 1971. Electron microscope heteroduplex methods for mapping regions in base sequence homology in nucleic acids. Methods Enzymol. 21D:413-428.

12. Dube, S., H.-J. Kung, W. Bender, N. Davidson, and W. Ostertag. 1976. Size, subunit composition, and secondary structure of the Friend virus genome. J. Virol. 20:264-272.

13. Filbert, J. E., R. M. McAllister, M. O. Nicolson, and R. 
V. Gilden. 1974. RD-114 virus infectivity assay by measurements of DNA polymerase activity and virus group specific antigen. Proc. Soc. Exp. Biol. Med. 145:366-370.

14. Fischinger, P., P. T. Peebles, S. Nomura, and D. Haapala. 1973. Isolation of an RD-114-like oncornavirus from a cat cell line. J. Virol. 11:978-985.

15. Gillespie, D., S. Gillespie, R. C. Gallo, J. L. East, and L. Dmochowski. 1973. Genetic origin of RD-114 and other RNA tumor viruses assayed by molecular hybridization. Nature (London) New Biol. 244:51-54.

16. Hellman, A., P. T. Peebles, J. E. Strickland, A. K Fowler, S. S. Kalter, S. Oroszlan, and R. V. Gilden. 1974. Baboon virus isolate M-7 with properties similar to feline virus RD-114. J. Virol. 14:133-138.

17. Hu, S., N. Davidson, and I. M. Verma. 1977. A heteroduplex study of the sequence relationships between the RNAs of M-MSV and M-MLV. Cell 10:469-478.

18. Junghaus, R. P., S. Hu, C. A. Knight, and N. Davidson. 1977. Heteroduplex analysis of avian RNA tumor viruses. Proc. Natl. Acad. Sci. U.S.A. 74:477-481.

19. Kalter, S. S., R. J. Helmke, M. Panigel, R. Heberling, P. J. Felsburg, and L. R. Axelrod. 1973. Observation of apparent C-type particles in baboon (Papio cynocephalus) placentas. Science 179:1332-1333.

20. Kung, H.-J., J. M. Bailey, N. Davidson, M. O. Nicolson, and R. M. McAllister. 1975. Structure, subunit composition, and molecular weight of RD-114 RNA. J. Virol. 16:397-411.

21. Kung, H.-J., S. Hu, W. Bender, J. M. Bailey, N. Davidson, M. O. Nicholson, and R. M. McAllister. 1976 RD-114, baboon, and woolly monkey viral RNAs compared in size and structure. Cell 7:609-620.

22. Livingston, D. M., and G. J. Todaro. 1973. Endogenous type-C virus from a cat cell line with properties distinct from previously described feline type-C virus. Virology 53:142-151.

23. Neiman, P. E. 1973. Measurement of RD-114 virus nucleotide sequences in feline cellular DNA. Nature (London) New Biol. 244:62-64.
24. Pal, B. K., R. M. McAllister, M. B. Gardner, and P. Roy-Burman. 1975. Comparative studies on the structural phosphaproteins of mammalian type $\mathrm{C}$ viruses. J. Virol. 16:123-131.

25. Rasheed, S., W. A. Nelson-Rees, E. M. Toth, P. Arnstein, and M. B. Gardner. 1974. Characterization of a newly derived human sarcoma cell line (HT-1080) Cancer 33:1027-1033.

26. Ruprecht, R. M., N. C. Goodman, and S. Spiegelman. 1973. Determination of natural host taxonomy of RNA tumor viruses by molecular hybridization: application to RD-114, a candidate human virus. Proc. Natl. Acad. Sci. U.S.A. 70:1437-1441.

27. Sarma, P. S., J. Tseng, Y. K. Lee, and R. V. Gilden. 1973. Virus similar to RD-114 in cat cells. Nature (London) New Biol. 244:56-58.

28. Sharp, P. A., M. T. Hsu, E. Ohtsubo, and N. Davidson 1972. Electron microscope heteroduplex studies of sequence relations among plasmids of $E$. coli I. Structure of F-prime factors. J. Mol. Biol. 71:471-497.

29. Sherr, C. J., M. M. Lieber, R. E. Benveniste, and G. J. Todaro. 1974. Endogenous baboon type $C$ virus (M7) biochemical and immunologic characterization. Virology 58:492-503

30. Staynov, D. Z., J. Pinder, and W. B. 'Gratzer. 1972 Molecular weight determination of nucleic acids by gel electrophoresis in non-aqueous solution. Nature (London) New Biol. 285:108-110.

31. Stephenson, J. R., R. K. Reynolds, and S. A. Aaronson. 1976. Comparisons of the immunological properties of two structural polypeptides of type C RNA viruses endogenous to Old World monkeys. J. Virol. 17:374384.

32. Todaro, G. J., and R. J. Huebner. 1972. The viral oncogen hypothesis: new evidence. Proc. Natl. Acad. Sci. U.S.A. 69:1009-1015.

33. Todaro, G. J., C. J. Sherr, R. E. Benveniste, M. M. Lieber, and J. L. Melnick. 1974. Type C virus of baboons: isolation from normal cell cultures. Cell 2:55-61. 